\title{
Shifting the Color Line
}

\section{Thomas J. Wilson Prize}

The Board of Syndics of Harvard University Press has awarded this book the twenty-seventh annual Thomas J. Wilson Prize, honoring the late director of the Press. The prize is awarded to the book chosen by the Syndics as the best first book accepted by the Press during the calendar year. 



\title{
Shifting the Color Line
}

Race and the American Welfare State

\author{
Robert C. Lieberman
}

Harvard University Press

Cambridge, Massachusetts, and London, England 
Copyright (C) 1998 by the President and Fellows of Harvard College All rights reserved

Printed in the United States of America

Second printing, 2001

First Harvard University Press paperback edition, 2001

Library of Congress Cataloging-in-Publication Data

Lieberman, Robert C., 1964-

Shifting the color line : race and the American welfare state /

Robert C. Lieberman.

p. $\mathrm{cm}$.

Includes bibliographical references and index.

ISBN 0-674-74562-0 (cloth)

ISBN 0-674-00711-5 (pbk.)

1. Afro-Americans-Politics and government.

2. Afro-Americans-Economic conditions.

3. Public welfare-United States.

4. United States-Social policy-1993-

5. United States-Race relations. I. Title.

E185.615.L4778 1998

$305.896^{\prime} 073-\mathrm{dc} 21 \quad 97-42373$ 
For Lauren 
